\title{
DESPRE FRONTIERA DUNĂRII DE JOS ÎN TIMPUL PRINCIPATULUI*
}

OVIDIU ȚENTEA

\author{
ABOUT THE LOWER DANUBE FRONTIER DURING THE PRINCIPATE
}

The scholarly stand point to see the large rivers as borders is due to the imagination of modern historians rather than to the mapping literary, epigraphic, and archaeological data. The achievement of the great historical atlases and their diffusion as teaching and research material, since mid $19^{\text {th }} \mathrm{c}$. up to now, has fundamentally influenced the way for reconstructing the historical past. Thus, one of the basic issues was to delimit territories inhabited by various populations, the trend being to separate them by natural borders or barriers. The location of the fortifications on the Danube should not be judged only from the view of the military strategic value, but mainly in terms of the opportunities to set up port facilities, as the river was firstly a supply route. As a result, the significance of the Roman fortification works should be argued by understanding of the communication system.

The inclusion of a vast territory located north to the Danube is atypical should we consider the previous enlargement of the Roman borders. The campaigns of the Roman armies carried out in here during the $1^{\text {st }} \mathrm{c}$. AD were interpreted as being designed to enforce onto the populations in this area a client status. In addition, certain modern authors argued for a so-called "security area/safety space".

The article discusses the situation of the limes at the Lower Danube and the related armies during the $1 \mathrm{st} \mathrm{c}$. $\mathrm{AD}$. The first major moment, involving the displacement of Legions V Macedonica and XI Claudia at Troesmis, respectively at Durostonum is linked to the period between Trajan's two Dacian campaigns, when the extension of the Roman fortifications' network along the Lower Danube may be recorded. The second important moment in the history of the limes in Lower Moesia was the displacement of Legion V Macedonica at Potaissa, during the Marcomannic Wars fought by Marcus Aurelius. Under such circumstances, the limes sector under the surveillance of this legion went under the control of Legion I ltalica, stationed at Novae, as evidenced by epigraphic finds.

KEYWORDS: Principate, frontier, Danube, armies, campaign

CUVINTE CHEIE: Principat, frontieră, Dunăre, armate, campanie

Reevaluarea rezultatelor cercetărilor arheologice de dată recentă, publicarea unui număr impresionant de diplome militare, cât și o oarecare efervescență produsă de organizarea unor manifestări tematice prilejuite de împlinirea a 1900 de ani de la cucerirea Daciei, respectiv de la inaugurarea Columnei lui Traian, sunt principalele cauze care au determinat creșterea considerabilă a numărului studiilor dedicate acestei teme. Acest fapt nu poate decât să fie benefic, atât pentru studiul campaniilor dacice cât și pentru unele fenomene influenţate major de aceste evenimente, iar lucrarea de față oferă câteva astfel de exemple.

Columna lui Traian ocupă un loc central în cadrul dezbaterilor privitoare la cucerirea Daciei. Deși din comentariile lui Traian despre campaniile dacice nu a putut fi reconstituit decât un mic pasaj ${ }^{1}$, în lucrarea lui Cichorius, şi ulterior, în cele mai multe interpretări istoriografice regăsim opinia potrivit căreia columna reprezintă o masivă ilustrare a conținutului acestei lucrări ${ }^{2}$. Astfel, imaginea ar fi reflectat realitatea însăşi, descompusă şi prezentată într-o manieră fidelă. Parcurgerea succesivă a scenelor nici nu are cum să nu influențeze interpretarea, această „modalitate de lectură" sugerând dispunerea în spirală a unui pergament sau microfilm. Nu pot să nu observ faptul că metodologic cea mai mare parte a lucrărilor de sinteză asupra reliefurilor

\footnotetext{
*Această lucrare a fost realizată în cadrul proiectului finațat de Ministerul Educației Naționale, CNCS - UEFISCDI, nr. PNII-ID-PCE-2012-4-0210.

I Priscianus, VI, 13, 205: inde Berzobim, deinde Aizi processimus.

${ }^{2}$ Cichorius 1900
} 
columnei lui Traian scrise în istoriografia românească se situează pe direcția deschisă de Cichorius, încercând să identifice topografic diferitele scene de pe monument, interpretând scenele într-o succesiune cronologică coerentă $\breve{a}^{3}$. Friza columnei oferă un Bildmedium, care permite direcții de citire atât pe orizontală cât și pe verticală, întrucât, deopotrivă descriptiv și tematic, principalele elemente pot fi regăsite din orice parte aceasta ar fi fost privită ${ }^{4}$.

Modalitatea în care istoricii moderni au înțeles și interpretat date literare, epigrafice referitoare la anumite campanii militare și, implicit, la extinderea frontierelor a fost influențată de cele mai multe ori de calculele şi estimările făcute pe hărți modeme, omiţându-se de cele mai multe ori că această perspectivă oferă o raportare diferită față de raționamentele de la care porneau ofițerii romani. Maniera în care sunt reprezentate cursurile marilor râuri ca frontiere se datorează mai degrabă unei imagini actuale pe care o au istoricii atunci când transpun cartografic date literare, epigrafice sau arheologice. Realizarea marilor atlase istorice şi distribuirea lor ca material didactic şi de cercetare au influențat esențial modalitatea de a reconstitui trecutul istoric. Astfel, una dintre problemele fundamentale a fost delimitarea ocupării unor teritorii de către diverse populații, tendința fiind aceea de separare a acestora prin granițe sau bariere naturale. Aș aminti tot aici și faptul că actuala configurație a statelor moderne a afectat, la rândul său, perspectiva prin care au fost interpretate anumite fenomene. Ca urmare, am putut observa tendința unor istorici români de a trata diferit anumite segmente de pe cursul inferior al Dunării; în zona dobrogeană, spre exemplu, au fost mult mai numeroase încercările de a identifica vaduri/zone de trecere, decât pe o porțiune mult mai semnificativă, situată în amonte, care astăzi coincide cu frontiera dintre două state moderne!

De cele mai multe ori, frontierele romane au fost înțelese prin prisma tendinței omului modern de a defini anumite entități regionale prin linii de separare, materializate prin granițe precise. Conceptul de frontieră își schimbă tot mai frecvent unele valențele și revine în actualitate și ca urmare a frecventelor dezbateri referitoare la funcționarea și extinderea spațiului Schengen sau a repoziționărilor strategice din nordul Mării Negre. Termenii discuțiilor tehnice și politice au ca bază un concept european văzut prin prisma oportunităților, dar și a riscurilor. În abordările istoriografice ale frontierei romane se pot decela perspectivele în care accentul cade pe autoritatea centrală care controla un teritoriu delimitat prin „Marele limes” şi perspectiva în care accentul cade pe zonele periferice, potrivit unei concepții minimaliste, în care frontierele erau cvasi-inexistente. Acestea au fost mai degrabă zone critice de interacțiune, întrucât economia Imperiului depindea, într-o măsură considerabilă, de relaţiile comerciale cu populațiile din vecinătate. Existența frontierelor imperiale şi a populațiilor din proximitatea acestora a jucat un rol foarte important în ideologia politică a Imperiului, fapt reliefat de textele literare antice, care relatează pe larg despre invazii și aspecte ținând de perspectiva politică a împăraților, în detrimentul aspectelor economice sau relațiilor dintre comunitățile situate în zonele de frontieră ${ }^{5}$. Rezultatele cercetărilor arheologice furnizează o multitudine de date referitoare la interacţiunea cu lumea barbară în zonele limitrofe şi nu numai. Frontierele au fost mai degrabă un spaţiu de tranziţie, motiv pentru care clasificarea acestora în „naturale” şi „artificiale”, ar trebui înlocuită cu termeni ca ,zone de separare” sau ,zone de legătură". Din această perspectivă, planificarea strategiilor militare s-ar fi fãcut prin raportarea la populațiile întâlnite și, implicit, la teritoriile ocupate de acestea și llu invers.

Cucerirea Daciei a fost amplu dezbătută în literatura de specialitate prin prisma aspectului particular pe care acest teritoriu îl are pe hărțile moderne. Extinderea fronticrelor în acest spațiu (370 mile, adică 1.000 .000 picioare romane $)^{6}$, fiind considerat un exemplu clasic de

\footnotetext{
${ }^{3}$ Pentru o scurtă evaluare a acestor interpretāri vezi Tentea 2014. Selectarea imaginilor și dispunerea acestora pe episoade şi scene reprezintă un ecou simplificat al „filmologiei” lui Malissard (1974) sau a compoziției de ansamblu a lui H. Stuart Jones (1910, 435-458). Lugli găsește o soluție conciliatoare, vorbind despre tripla semnificaţie a columnei, topografică, istorică şi funerară, motivul ridicării ei fiind glorificarea armatei romane și a Romei imperialc în onoarea lui Traian (Lugli $1943,835-842)$.

${ }^{4}$ Galinier 2007, 94-97; Strobel 2010, 236-238. In cea mai recentā lucrare a sa despre epoca lui Traian, Strobel se pronunța foarte plastic împotriva ideii de „Dokumentarfilm”, propunând sintagma de „Bildmedium” (Strobel 2010).

${ }^{5}$ Isaac 1990; Whittaker 1994

${ }^{6}$ Nemeti 2011, 37-38, 46
} 
vulnerabilitate la nivelul presupusei strategiei generale a Imperiului Roman ${ }^{7}$. Agrippa ${ }^{8}$, care a impărtășit probabil opinia predominantă a nordului Europei aplatizat, a plasat Oceanul la doar 400

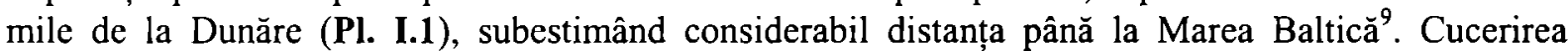
întregului areal din Europa de est părea, așadar, un obiectiv accesibil în timpul lui Traian. O jumătate de secol mai târziu, Marcus Aurelius piănuia la rândul său să creeze noi provincii în nord, Sarmatia și Marcomannia (Historia Augusta, Marcus Aurelius 27.10), campanie în urma căreia, eventual, ar fi putut să ajungă, din nou, la ocean ${ }^{10}$. Sursele cartografice de care dispunem provin din activitățile de exploratio realizate în timpul campaniilor militare sau din activitatea unor agrimensores, care au măsurat teritoriul noilor provincii" ${ }^{11}$. În acest context, amintim și faptul că mai mulți autori plasează redactarea hărții IX a lui Ptolemeu (bazată pe lucrări anterioare ca itineraria, periplus), pe care figurează Dacia și zona Dunării de Jos, în prima parte a secolului al II-lea, cândva după cucerirea Daciei $^{12}$.

Momentul definitoriu, care poate fi pus în legătură cu decizia construirii unui sistem defensiv coerent în zona Dunării inferioare, a fost atacul sarmaţilor din iama anului 101 asupra garnizoanelor romane concentrate în arealul garnizoanelor legionare de la Novae și Oescus ${ }^{13}$. Acest atac s-a datorat în primul rând sarmaţilor roxolani, în acel moment aliaţi ai dacilor ${ }^{14}$. Așa-numita diversiune moesicăa ${ }^{15}$ a lui Decebal este mai degrabă o metaforă istoriografică, generată - în principal - de interpretarea narativă a frizei de pe columna lui Traian. Atât reprezentarea dacilor alături de sarmați în scenele respective, cât și restituirea inscripției de la Adamclisi ${ }^{16}$ pot fi văzute mai degrabă ca expresii ale contextualizări unor episoade din bellum dacicum Traiani, din care dacii nu puteau lipsi. Istoricii care l-au văzut pe Decebal ca fiind un rege al unui vast stat al dacilor, i-au atribuit acestuia o viziune strategică aparte care, asemeni operațiunilor din diversiunea moesică, nu credem că i-au aparținut. Tot din această perspectivă credem că au fost interpretate și prea numeroasele direcții prin care armata romană ar fí atacat Regatul dacic ${ }^{17}$.

Misiunea sarmaților a fost prădarea teritoriilor din dreapta Dunăriii ${ }^{18}$. Faptul că aceștia au atacat armatele romane concentrate în nord-vestul provinciei, între Oescus și Novae, este indicat de faptul că de locul celei mai importante bătălii cunoscute, Nicopolis ad Istrum, se află situat în apropiere. După atacul din iarna anului 101-102, în această zonă sunt atestate măsuri de suplimentare a efectivelor. La Oescus a fost adusă legiunea $X I$ Claudia $^{19}$, pentru a suplini efectivele dislocate din legiunea $V$ Macedonica. La Novae, în locul efectivelor dislocate sau decimate din legiunea I Italica, a fost adusă o vexilaţie sau poate

\footnotetext{
${ }^{7}$ Includerea unui întins teritoriu situat la nordul Dunārii a fost atipică dacă luăm în considerare extinderile anterioare ale frontierelor romane (Luttwak 1976, 100; Bogdan Cătăniciu 1981; Petolescu 1986, 510-513; Poulter 1986, 528; Zahariade 1997, 603-606; Wheeler 2010, 1185-1227). Campaniile armatelor romane efectuate la nordul Dunării pe durata secolului I p. Chr. au fost interpretate a fi avut scopul de a impune populațiilor din acest areal un statut clientelar (Pârvan 1926, 733; Syme 1971, 148-149; Pippidi 1967, 306), ocazii cu care unii autori moderni au fost de părere că a fost creată o aşa-numită „zonă de securitate/spațiu de siguranță” prin mutarea a zeci de mii de transdanuviani la sudul Dunării şi interzicerea constituirii ulterioare a unor noi așezări civile. În timpul lui Augustus, Aelius Catus a mutat 50.000 de getae de la nordul Dunārii în Thracia (Strabo 7.3.10); sub Nero, Ti. Plautius Silvanus a mutat 100.000 de transdanuviani la sudul Dunării, făcându-i plătitori de taxe (ILS 986).

B Tiemey 1964,151-166

9 Nemeti 2011, 38

${ }^{10}$ Mattern 1999, 61

1 Austin, Rankov 1995, 112 sqq.

${ }_{12}^{12}$ Bogdan Cătăniciu 1988, 145-162; Nemeti, Bărbulescu 2007, 110; Nemeti 2011, 38

13 Trupele romane aflate sub comanda guvematorului Moesiei Inferior erau concentrate aici într-o adevăratā bază de operațiuni unde se adunau trupele provinciei. O situație similară o constituie arealul din zona fortificațiilor Sirmium și Viminacium (Moesia Superior). Alte exemple de concentrări de trupe într-un areal bine conturat teritorial, în vederea participării la campanii în teritorii extra-porvincial sunt Apsarus (Cappadocia) sau Syrene (Egipt) (Speidel 1986, 657-660; Ruscu, Ruscu 1996, 227-228) precum şi Porolissum (Ruscu, Ruscu 1996, 227), Tibiscum sau Micia.

${ }^{14}$ Pentru două evaluări mai recente, vezi Bârcă 2006, 18; Bârcă 2013, 117.

${ }^{15}$ Pentru reunirea celor mai multe opinii, vezi mai recent Petolescu 2010, 140.

${ }^{16}$ CIL III 12467 = AE 1965, 276; IDRE II 334: [devicto exerc] itu D[acorum et Sarmata]rum - Emilia Doruțiu-Boilă, C. C. Petolescu.

${ }^{17}$ Vezi nota 29.

${ }^{18}$ Stefan 2005, fig. 235

${ }^{19}$ ILB 62; Matei-Popescu 2010, 262
} 
întreaga legiune I Minervia, condusă de către viitorul împărat Hadrian ${ }^{20}$. Mutarea acestora din Germania Superior, respectiv din Germania Inferior, precum şi a unor trupe auxiliare ${ }^{21}$ a avut aşadar rolul de a întări o zona vulnerabilizată, respectiv de a compensa pierderile suferite în urma atacurilor roxolanilor. $\mathrm{Nu}$ putem şti cu exactitate dacă în cursul anului 101 efective din trupele Moesiei Inferior vor fi fost implicate în operațiuni la nordul Dunării sau această decizie a fost luată doar în anul următor. Este important de precizat faptul că implicarea armatelor din Moesia Inferior nu s-a petrecut concomitent cu a celor din Moesia Superior sau Pannonia ${ }^{22}$. Este mult mai probabil ca aceste trupe să fi participat masiv la operațiuni la nordul Dunării după atacul amintit al sarmaților roxolani.

Aceștia nu au participat la cea de-a doua campanie dacică a lui Traian, fapt care poate fi pus în legătură cu încheierea unui armistițiu după prima campanie, care va dura până la finele domniei împăratului ${ }^{23}$. Incursiunea lor la dreapta Dunării trebuie să fi început pe teritoriul Dobrogei, unde nu întâmplător - după încheierea păcii în 102 - vor fi consemnate măsuri importante de consolidare a frontierei.

Acum vor fi dislocate legiunea $V$ Macedonica la Troesmis și legiunea XI Claudia la Durostorum; este un interval cronologic în care, potrivit surselor arheologice şi epigrafice, au fost construite castrele de la Carsium (în anul 103) ${ }^{24}$, Rasova-Flaviana $(105-108 \text { ? })^{25}$, precum și cel puțin o parte dintr-un drum, potrivit miliarului descoperit la Sacidava (dedicat de cohors $I V$ Gallorum, între anii $103-105)^{26}$. Această activitate de fortificare a cursului inferior al Dunării o vedem ca fiind o expresie a acordului cu sarmații, materializată în teren sub forma unei delimitări teritoriale clare. Dislocarea trupelor auxiliare trebuie evident pusã în corelaţie cu mutarea legiunilor la Durostorum și Troesmis $^{27}$.

În acest interval, sau cel mai târziu după cucerirea Daciei, au fost abandonate castrele de pe cursul Dunării cuprinse între Viminacium și Novae, cel puțin pe durata primei jumătăți a secolului al II-lea p. Chr. ${ }^{28}$. Trupele cantonate în aceste castre au fost dislocate în provincia nou creată la nordul Dunării (din Moesia Superior), respectiv în anumite teritorii de la est de Olt (din Moesia Inferior) ${ }^{29}$.

Discuția privitoare la constituirea frontierei romane în arealul Dunării de Jos nu poate fi separată, în prima parte a secolului al II-lea p. Chr., de numeroasele mișcări de armate romane în operațiunile desfășurate la nordul Dunării, pe teritoriul Munteniei. După sfârşitul războiului dacic al lui Traian, teritoriile ocupate au avut statute diferite, fapt reflectat şi în diversitatea soluțiilor administrative adoptate pentru un deceniu. Existența unor fortificații romane din zona colinară a

${ }^{20}$ Prezența legiunii I Minervia la Novae a fost atestată prin ştampile tegulare descoperite în context arheologic bine datat. Vezi şi discuția la Matei-Popescu 2007, 290.

${ }^{21}$ Matei-Popescu, Tentea 2006a, 56-65

22 Matei-Popescu, Tentea 2006, 100

${ }^{23}$ Istoria Augusta, Hadrianus, 6, 6-8; Opreanu 1994, 207

${ }^{24}$ Datare dupã numele guvematorului $Q$. Fabius Postuminus (103 p. Chr.) - ISM V 94, p. 120-121; Opriş 2006, 241 , fig. 1.

${ }^{25}$ Datare după numele guvematorului L. Fabius Iustus (105-108 p. Chr.), Rasova (jud. Constanța), Rădulescu, Bărbulescu 1981, 586-588, fig. 2; Opriş 2006, 241, fig. 2-3.

26 Rădulescu, Bărbulescu 1981, nr. 1, 353-356; pentru cohors IV Gallorum, vezi și Matei-Popescu 2004, 208-210; Matei-Popescu 2010, 32. Vezi şi discuția la Opriș 2006, 237-242.

${ }^{27}$ Până în timpul domniei lui Traian nu se cunoşteau fortificații romane pe malul drept al Dunării între bazele navale de la Sexaginta Prisca (Ruse) şi Noviodunum (Isaccea), responsabilitatea supravegherii acestui trasei revenind unui praefectus classis Flavia Moesice et ripae Danuvii (AE 1972, 572). Inscripția, datată în timpul domniei lui Domitian (IDRE II 373), pare a fi o dovada faptului că până în perioada lui Traian, ripa Danuvii se afla sub autoritatea prefectului flotei (MateiPopescu 2010, 251). Singura descoperire epigrafică care atestă o prezențā a armatei romane în această zonă, înainte de Traian provine de la Aegyssus (CIL III 6221 = ISM V 286). Interesant de observat este faptul că întregul sector dunărean corespunzător provinciei Moesia Inferior a fost supravegheat atât de classis Flavia Moesica, cât şi de flota legiunii I Italica (Sarnowski, Trynkowski 1986, 536-541). Nu sunt cunoscute până acum atestările ale legiunii V Macedonica sau legiunii XI Claudia care să poată fi puse în legătură cu activități portuare, sau cu existența unor flotile ale acestor legiuni care sã activeze pe cursul inferior al Dunării. Cu atât mai interesantă este absența atestărilor legiunii XI Claudia în aval de Durostorum dupã plecarea legiunii V Macedonica de la Troesmis.

${ }^{28}$ Mirković 2002, 757. În timpul lui Marcus Aurelius, apărarea Daciei a căzut în sarcina armatei Moesiei Superior, perioadă de când datează probabil încercările de a restabili sistemul defensiv de-a lungul acestei porțiuni a Dunării. Revenirea la sistemul defensiv care exista în timpul lui Traian s-a realizat în timpul lui Septimius Severus sau al lui Caracalla, când au fost reluate staționările de trupe în castrele de la Novae, Taliata, Diana sau Pontes, reconstruindu-se frontiera până la Acumincum (Mirković 2002, 762).

${ }^{29}$ Matei-Popescu, Tentea 2006, 100-101 
Munteniei (Drajna, Mălăiești și Târgșor) a implicat construirea mai multor scenarii privind avansarea armatei Moesiei Inferior la nordul Dunării, urmărind rutele ce porneau din castrele legionare de la sudul Dunării, Troesmis, Durostorum, Novae sau de la Barboși, pe valea Siretului, pe valea Buzăului și pe Valea Ialomiței ${ }^{30}$. Scenariile potrivit cărora armatele romane din Moesia Inferior ar fi pătruns la nordul Dunării pe multiple direcții de atac, realizând adevărate învăluiri, au avut ca premisă teoretică existența unui regat dac puternic, condus de Decebal. Folosind ca punct de pornire acest scenariu, unii autori erau de părere că fortificațiile romane amintite ar fi avut rolul ca, împreună cu altele presupuse a fi funcționat în zona Moldovei, să fii blocat toate văile care constituiau căi de acces spre Transilvania, anihilând astfel posibilitatea unor atacuri surpriză ale dacilor după prima campanie dacică a impăratului Traian $(101 / 102)^{31}$.

În opinia noastră, armatele romane au pornit în campaniile de la nordul Dunării din castrele legionare de la Oescus și Novae, urmând două direcții distincte: aliniamentul Oltului, cât și drumul de pe linia numită transalutană, care ajunge în nord până la pasurile montane, şi asigură accesul spre sudestul Transilvaniei. Coloane de atac sau rutele dinspre Troesmis, Barboși, pe drumul spre Poiana sau direct spre Valea Buzăului, sau dinspre Durostorum către arealul zonelor subcarpatice din Muntenia nu ar mai trebui căutate.

Organizarea unei frontiere riguroase nu putea fí realizată fără a se ține seama de caracterul nomad al populațiilor situate în proximitatea acestui spațiu, în cazul de față referindu-ne doar la sarmaţi. Observarea caracterului fortificaţiilor liniare din zonele de contact cu aceştia indică o preocupare aparte a romanilor în adoptarea unor soluții optime pentru buna funcționare a frontierelor ${ }^{32}$.

În urma negocierilor cu aceste populații, Hadrian redimensionează sistemul defensiv în provinciile afectate, dislocând - într-o serie de puncte cheie - trupe auxiliare dintre care se disting cele foarte mobile, datorită efectivelor de cavalerie. De asemenea, acesta optează pentru trupe neregulate specializate. Se remarcă adaptabilitatea la particularitatea Daciei, gândirea în detaliu a unor soluții strategice şi, de ce nu, economice. Întreținerea noilor trupe era mai ieftină, acestea fiind adaptabile, probabil mai puțin pretențioase la condițiile existente în nou creata provincie.

Trupele auxiliare dislocate în unele zone colinare ale Munteniei au fost mutate în cea mai mare parte în provincia Dacia Inferior ${ }^{33}$ (estul Olteniei și în sud-estul Transilvaniei), iar vexilațiile legionare au fost retrase în castrele de la sudul Dunării. Tot acum sunt abandonate castrele de la Drajna, Mălăiești, Târgșor, Pietroasele, Voinești, Rucăr și, probabil, Buridava. Armata noii provincii Dacia Inferior era compusă, cu două excepţi, din trupele auxiliare ale Moesiei Inferior detaşate la nordul Dunării încă din timpul campaniilor dacice ale lui Traian ${ }^{34}$.

Următorul moment important în istoria limesului din Moesia Inferior a fost mutarea legiunii $V$ Macedonica la Potaissa, în contextul războaielor marcomanice din timpul lui Marcus Aurelius. În aceste condiţii, sectorul de limes aflat sub supravegherea legiunii $V$ Macedonica a intrat sub controlul legiunii I Italica, ce staţiona la Novae, după cum indică descoperirile epigrafice. În acelaşi timp, atestările epigrafice ale legiunii XI Claudia de la Durostorum nu depăşesc spre nord Capidava, cu excepţia ariei central nordice a Dobrogei. Distribuţia trupelor a rămas în cea mai mare parte neschimbată de-a lungul perioadei Principatului, acestea staționând cu predilecție în fortificații dispuse în vecinătatea Dunării.

\footnotetext{
${ }^{30}$ Tocilescu 1900, 127; Pârvan 1923, 140-142; Petolescu 2001, 350; Zahariade, Lichiardopol 2006, 121, 126; Petolescu, Matei-Popescu 2008, 359

${ }^{31}$ Petolescu 1986, 510-513; Bogdan Cătăniciu 1997, 49-50; Petolescu, Matei-Popescu 2008, 359

32 Tentea, Oltean 2009, 1515-1524

${ }^{33}$ Matei-Popescu 2004, 173-242; Matei-Popescu 2010, 257-269

${ }^{34}$ Petolescu, Matei-Popescu 2008, 365-366; Matei-Popescu 2010, 269
} 
Datorită multitudinii de informații apărute în urma publicării a numeroase diplome militare, au fost semnalate aspecte detaliate privitoare la trupele auxiliare, dislocarea și rolul acestora. Dacă în cadrul sistemului defensiv al provinciilor aceste trupe au un rol tactic, legiunile trebuie privite în contextul strategiei gândite pentru zona respectiva $a^{35}$; acest fapt poate fi observat în privința dislocării legiunilor Moesiei Inferior pe durata secolului al II-lea p. Chr.

Amplasarea fortificațiilor pe Dunăre nu trebuie judecată numai din perspectiva componentei de strategie militară, ci și prin prisma condițiilor de amenajări portuare, deoarece râul era în primul rând o rută de aprovizionare. Semnificația lucrărilor de fortificații romane trebuie să fie argumentată așadar de înțelegerea sistemului de comunicații ${ }^{36}$. Termenul de „frontieră” nu este echivalent cu cel de graniţă sau linie de separare între entități statale, provincii sau triburi. Acest fapt se poate observa în arealul în discuție din dovezile epigrafice care atestă încă de timpuriu classis Flavia Moesica ${ }^{37}$ și semnificativ mai târziu unitățile de uscat, care la început au avut rolul de a asigura securitatea transporturilor pe Dunăre.

După cum aminteam, hărțile antice erau ghiduri schematice realizate pentru uzul militarilor şi al negustorilor, sub forma unor itinerarii rutiere, care conțineau scurte note explicative ale unor obiective. Acestea nu erau redate într-o perspectivă geografică şi nici politică, întrucât frontierele, ca limite ale Imperiului, nu erau marcate ${ }^{38}$. Din acest considerent am încercat să interpretăm unele aspecte privitoare la frontiera romană de pe cursul inferior al Dunării în conexiune cu perspectiva pe care ne-o oferã harta lui Ptolemeu (Pl. I/2) sau Tabula Peutingeriana (PI. I/3) ${ }^{39}$. Spre exemplu, harta semnată de Petrus Kaerius constituie o redescoperire a lui Ptolemeu, transpus într-o versiune care reflectă și realități medievale. Detaliul relevant pentru discuția noastră îl constituie cursul inferior al Dunării, reprezentat ca o proiecție aproximativ liniară, ușor oblică spre gura de vărsare (Pl. II/1). Diferențele față de maniera de reprezentare din Tabula Peutingeriana (PI. I/3) sunt minore, deşi acestea sunt despărțite de un interval cronologic apreciabil. Perspective identice sunt întâlnite şi în hărțile realizate mai târziu, chiar și pe durata secolului al XVIII-lea (PI. II/2-3). Această manieră de reprezentare, destul de depărtată de realitățile geografice din teren, indică, pe lângă precauția pe care istoricii contemporani trebuie s-o aibă atunci când recompun realități istorice pe baza unor informații la care anticii nu vor fi avut acces, și o posibilă direcție de studiu ce poate fi avută în vedere în momentul în care sunt interpretate date istorice cunoscute, precum în cazul de față frontiera romană.

Din această perspectivă poate fî înțeles mai bine rolul legiunilor în arealul analizat. Ştampilele tegulare atestate pe sectorul dunărean corespunzător provinciei Moesia Inferior indică activități de transport și supraveghere realizate de classis Flavia Moesica ${ }^{40}$ și de flota legiunii I Italica ${ }^{41}$. Nu sunt cunoscute până acum atestări ale legiunii $V$ Macedonica sau ale XI Claudia care să poată fi puse în legătură cu activități portuare sau cu existența unor flotile aparținând acestor legiuni, care vor fi activat pe cursul inferior al Dunării. Foarte interesante ni se par atestările sporadice ale legiunii XI Claudia în aval de Capidava, mai ales după plecarea legiunii $V$ Macedonica de la Troesmis. Nu același lucru se poate afirma despre atestările legiunii I Italica. Implicarea acesteia în activitățile portuare și de patrulare pe Dunăre a fost atât de bine structurată încât după plecarea legiunii $V$ Macedonica de la

\footnotetext{
${ }^{35}$ Istoricii modemi au definit termenul de tactică în raport cu o bătălie/conflict, ccl de strategie cu referire la război, iar diversele dislocări fiind acoperite de termenul de „operațiune”. Toți acești termeni pot fi adaptat cu uşurință la realitățile perioadei romane. Conceptul „Grand Strategy of the Roman Empire” (Luttwak 1976), promovat in lucrarea lui E.N. Luttwak (un istoric militar care s-a ocupat de numeroase epoci istorice şi care utiliza acelaşi concept în lucrarea sa privitoare la Imperiul Bizantin) a produs o întreagà efervescență în dezbaterea istoriografică, polarizând o mare parte din dezbaterile privitoare la ammata romană. $O$ parte a fost tentată sã promoveze argumentația acestei teorii, incluzând in această "mare strategie" sferele economicului şi diplomației (Mattem 1999, 81 ). O direcție cu totul aparte vine însă dinspre o abordare mult mai elastică, care ține seama de elementele specifice periferiei Imperiului, precum şi de numeroşi alți factori locali (Wheeler 1993, part 1, 21-22).

36 Isaac 1990, 128. Râurile nu erau obstacole tactice prea importante. Potrivit expresiei unui general modern, acestea împiedicau doar „călăreții încărcați cu pradă” (Whittaker 1994, 24, note 56).

${ }^{37}$ Matci-Popescu 2010, 29, 245-246

${ }^{38}$ Whittaker 2004, 11, 82

${ }^{39}$ Talbert 2010

40 Raza de acţiune a classis Flavia Moesica a fost, probabil încă de la organizarea ei, sectorul dobrogean al Dunănii: Troesmis, Barboși, Dinogetia, Noviodunum, Cartal-Orlovka (Aliobrix?) - ISM V 217, 241, 263, 283.

${ }^{4 !}$ Samowski, Trynkowski 1986, 536-541
} 
Troesmis, o parte din activitățile acesteia au fost preluate de către efective din I Italica şi nu din XI Claudia, cum am fi fost tentați să deducem logic. Activitatea legiunii XI Claudia pare să fi fost mai degrabă orientată spre Tomis și către zona Mării Negre, de unde probabil provine şi Pontica, utilizat ca agnomen al acestei legiuni ${ }^{42}$. Remarcăm faptul că, ulterior mutării legiunii $V$ Macedonica în Dacia, comanda acestor vexilaţii dislocate la nordul Mării Negre a revenit tribunilor angusticlavi din legiunea I Italica ${ }^{43}$. Distribuția materialului ceramic de construcție purtând ștampila legiunii I Italica în numeroase situri de-a lungul cursului inferior al Dunării se explică prin faptul că această legiune avea la dispoziţie escadre navale proprii (navalia legionis), care îi înlesneau circulaţia între castrul de la Novae și porturile aflate sub control ${ }^{44}$.

Dar, despre alte elemente referitoare la arheologia peisajului sau de geografia istorică la Dunărea de Jos în perioada Principatului, vom discuta însă cu altă ocazie.

\section{BIBLIOGRAFIE}

\section{SURSE ANTICE}

Cassius Dio

Historia Augusta

Strabo

\section{SURSE CARTOGRAFICE}

Kaerius 1650

Rossi 1684

Nolin 1716

Austin, Rankov 1995

Bârcă 2006

Bârcă 2013
Dio Cassius, Roman History, vol. I-IX, translated by Eamest Cary, on the basis of the version of Herbert Baldwin, Loeb Classical Library, 1914-1927

Historia Augusta, vol. I-III, Translated by David Magie, Loeb Classical Library, 1921-1932

Strabo, Geography, vol. I-VIII, Translated by Horace Leonard Jones, Loeb Classical Library, 1917-1932

Petrus Kaerius (Pieter van der Keere), Vetus Descriptio Daciarum nec non Moesiarum, Amsterdam 1650 (disponibilă on-line la adresa http://www.raremaps.com/gallery/enlarge/29803lh, accesată în 15.05.2013)

G.G. Rossi, Corso del Danubio da Belgrado fino al Mar Nero con Provincie, che intorno al medesimo ..., Roma, 1684 (disponibilă la adresa https://www.raremaps.com/gallery/enlarge/29230, accesată în accesată în 15.05.2013)

J.B. Nolin, Vincenzo Maria Coronelli, Cours du Danube: Depuis sa source jusqu'a ses embouchures ou sont partie de l'Empire d'Allemagne et des Estates qui ont este ou qui sont encore de l'Empire du Turcs en Europe ..., Paris 1716 (disponibilă la adresa http://www.raremaps.com/gallery/enlarge/32692mp, accesată în 15.05.2013)

N.J.E. Austin, N. B. Rankov, Exploratio. Military and political intelligence in the Roman World from the Second Punic War to the battle of Adrianopole, London New York, 1995

V. Bârcă, Sarmații - aliați ai dacilor în războaiele contra Romei, în Dacia Augusti provincia, p. 3-28

V. Bârcă, Nomads of the Steppes by the Danube Frontier of the Roman Empire in the 1st Century AD. Historical Sketch and Chronological Remarks, Dacia N.S. 57, p. $99-125$

\footnotetext{
${ }^{42}$ Matei-Popescu 2010, 136

${ }^{43}$ Matei-Popescu 2010, 278-279

44 În acest sens ar putea fi explicate numeroasele ştampile în care numele legiunii este figurat într-un cartuş de forma unei nave; Sarnowski, Trynkowski 1986, 536, 540.
} 
Bogdan Cătăniciu 1981

Bogdan Cătăniciu 1997

Bogdan Cătăniciu 1988

Cichorius 1900

Dacia Augusti Provincia

Fodorean 2014

Galinier 2007

Limes 13 Aalen

Isaac 1990

Lugli 1943

Luttwak 1976

Malissard 1974

Matei-Popescu 2004

Matei-Popescu 2007

Matei-Popescu 2010

Matei-Popescu,

Tentea 2006

Matei-Popescu,

Tentea 2006a

\section{Mattem 1999}

Mirković 2002

Nemeti 2011

Nemeti, Bărbulescu 2007

Pârvan 1923

Pârvan 1926

Petolescu 1986

Petolescu 2001

Petolescu 2010

Matei-Popescu 2008
I. Bogdan Cătăniciu, Evolution of the System of Defense Work in Roman Dacia, BAR 116, Oxford, 1981

I. Bogdan Cătăniciu, Muntenia în sistemul defensiv al Imperiului Roman. Wallachia in the Defensive System of the Roman Empire 1st-3th centuries A.D., Alexandria, 1997

I. Bogdan Cătăniciu, Ptolemeu şi provincia Dacia, ActaMN 24-25, 1988, p. 145162

C. Cichorius, Die Reliefs der Trajanssäule, vol. I-IV, Berlin, 1896-1900

Dacia Augusti Provincia. Crearea provinciei. Actele simpozionului desfăşurat 1314 octombrie 2006 la Muzeul Naţional de Istorie a României (ed. E.S. Teodor, O. Tentea), Bucureşti 2006

F. Fodorean, Maps of Roman Dacia. I. The map of Petrus Kaerius (1571-1646), Journal of Ancient History and Archaeology I. 1, 2014 (disponibil on-line http://jaha.org.ro/index.php/JAHA/article/view/14/20)

M. Galinier, La Colonne Trajane et les Forums Impériaux (Collection de l'École française de Rome 382), Rome, 2007

Studien zu den Militärgrenzen Roms III. Akten des 13. Internationalen Limeskongresses Aalen 1983, Stuttgart 1986

B. Isaac, The Limits of Empire: The Roman Army in the East, Oxford, 1990

G. Lugli, Il triplice significato: topografico, storico e funerario della Colonna Traiana, AARMSI s. III, t. XXV, 1943, p. 835-842

E.N. Luttwak, The grand strategy of the Roman Empire, Baltimore-London, 1976 A. Malissard, Etude filmique de la colonne Trajane. L'écriture de l'histoire et de l'épopée latine dans les rapports avec le langage filmique, Tours, 1974

Fl. Matei-Popescu, Trupele auxiliare romane din Moesia Inferior, SCIVA 52-53, 2004, p. 173-242

Fl. Matei-Popescu, Participarea legiunilor din Moesia Inferior la expedițiile dacice ale lui Traian, în Dacia Felix. Studia Michaeli Bărbulescu oblata (eds. S. Nemeti, F. Fodorean, E. Nemeth, S. Cociș, I. Nemeti, M. Pîslaru,), Cluj-Napoca, p. 290300

Fl. Matei-Popescu, The Roman Army in Moesia Inferior, Bucharest, 2010

Fl. Matei-Popescu, O. Tentea, The Participation of Upper Moesian Auxiliary Units to the Trajans Dacian Wars, Dacia N.S. 50, p. 127-140

Fl. Matei-Popescu, O. Țentea, Participarea trupelor auxiliare din Moesia Superior şi Moesia Inferior la cucerirea Daciei, în Dacia Augusti Provincia, 2006, p. 75 120

S. P. Mattern, Rome and the Enemy. Imperial Strategy in the Principate, Berkeley -Los Angeles-London, 1999

M. Mirković, Deserted Forts - The Moesian limes after the Conquest of Dacia, în Limes XVIII. Proceedings of the XVIIIth International Congress of Roman Frontier Studies held in Amman, Jordan (September 2000), BAR IntSer 1084, (eds. Ph. Freeman, J. Bennett, Z. T. Fiema, B. Hoffmann), 2002, p. 757-764

S. Nemeti, In circuitu tenuit ... Dacia and Roman Geographical Knowledge, Eph. Nap. 21, 2011, p. 37-50

S. Nemeti, M. Bărbulescu, Territorivm Arcobadarense, Eph. Nap. 16-17, 20062007, 107-116

V. Pârvan, Inceputurile vietii romane la Gurile Dunării, București, 1923

V. Pârvan, Getica. O protoistorie a Daciei, București, 1926

C.C. Petolescu, Les camps de la zone sud-carpatique de la Dacie, în Limes 13 Aalen, 1986, p. 510-514

C.C. Petolescu, Contribuţia militară a provinciei Moesia Inferior la cucerirea Daciei, Pontica 33-34, 2000-2001, p. 349-354 = C.C. Petolescu, Contribuții la istoria Daciei romane, București, 2007, p. 40-46

C.C. Petolescu, Dacia. Un mileniu de istorie, București, 2010

C.C. Petolescu, Fl. Matei-Popescu, The Presence of the Roman Army from Moesia Inferior at the North of the Danube and Making of the Dacia Inferior Province, in Die Römischen Provinzen. Begriff und Gründung (Colloquium Cluj-Napoca. September-1. Oktober 2006), ed. I. Piso, Cluj-Napoca, p. 357-368 
Pippidi 1967

Poulter 1986

Opriş 2006

Rădulescu,

Bărbulescu 1981

Ruscu, Ruscu 1996

Sarnowski, Trynkowski 1986

Speidel 1986

Stefan 2005

Strobel 2010

Stuart Jones 1910

Syme 1971

Talbert 2010

Tierney 1964

Tocilescu 1900

Țentea 2014

Țentea, Oltean 2009

Wheeler 1993

Wheeler 2010

Whittaker 1994

Whittaker 2004

Zahariade 1997

Zahariade, Lichiardopol 2006
D.M. Pippidi, Contribufii la istoria veche a României, ed. 2, București, 1967

A.G. Poulter, The Lower Moesian Limes and the Dacian Wars of Trajan, în Limes 13 Aalen, 1986, p. $519-528$

I.C. Opriş, Fortificarea limesului dobrogean de la Dunărea de Jos în preajma războaielor daco-romane, în Dacia Augusti Provincia, p. 237-248

A. Rădulescu, M. Bărbulescu, De nouveau sur les légats de Trajan en Mésie Inférieure entre 103 et 108 de n.é., Dacia N.S. 25, 1981, p. 353-358

D. Ruscu, Ligia Ruscu, EKTA $\Xi I \Sigma$ KATA A $\Lambda$ AN $\Omega N$ a lui Arrian şi strategia defensivă a Imperiului Roman în epoca hadrianică. Die Schlachtordnung gegen die Alanen de Arrian, Eph. Nap. 6, 1996, p. 205-259

T. Sarnowski, J. Trynkowski, Legio I Italica-Liburna-Danuvius, în Limes 13 Aalen, 1986, p. 536-541

M.P. Speidel, The Caucasus Frontier: Second Century Garrisons at Apsarus, Petra and Phasis, în Limes 13 Aalen, p. 657-660 = Roman Army Studies 1I, Stuttgart, 1992

Al. S. Stefan, Les guerres daciques de Domitien et de Trajan: Architecture militaire, topographie, images et histoire (Collection de l'École Française de Rome 353), Rome, 2005

K. Strobel, Kaiser Traian. Eine Epoche der Weltgeschichte, Regensburg, 2010

H. Stuart Jones, The Historical Interpretation of the Reliefs of the Trajan's Column, Papers of the British School at Rome, V, p. 435-458

R. Syme, Danubian Papers, Bucharest, 1971

R.J.A. Talbert, Rome's World: The Peutinger Map Reconsidered, Cambridge (disponibil on-line la adresa http://peutinger.atlantides.org/map-a, accesat la 15.05.2013)

J.J. Tiemey, The Map of Agrippa, Proceedings of the Royal Irish Academy. Section C: Archaeology, Celtic Studies, History, Linguistics, Literature 63, 19621964, p. 151-166

Gr. Tocilescu, Fouilles et recherches archeologiques, Bucarest, 1900

O. Țentea, Possiamo parlare oggi delle guerre daciche senza la Colonna traiana?, Ephemeris Dacoromana 16, 2014

O. Ţentea, I.A. Oltean, The Lower Danube Roman Limes at Galați (Romania). Recent results from excavation and aerial photographic interpretation, î Limes XX. XX Congreso Internacional de Estudios sobre la Frontiera Romana. XXth International Congress of Roman Frontier Studies, Léon (España), Septembre, 2006 (eds. Á. Morillo, N. Hanel, Esperanza Martín), Anejos de Gladius 13, 1-3, Madrid, p. 1515-1524

E.L. Wheeler, Methodological Limits and the Mirage of Roman Strategy: Part I, The Journal of Military History 57, 1, p. 7-41

E.L. Wheeler, Rome's Dacian Wars: Domitian, Trajan, and Strategy on the Danube, Part I, The Journal of Military History, 74, p. 1185-1227

C.R. Whittaker, Frontiers of the Roman Empire: A Social and Economic Study, Baltimore, 1994

C.R. Whittaker, Rome and its Frontiers: The Dynamics of Empire, London, 1997

M. Zahariade, Strategy and tactics in Roman Dacia, in Proceedings of the XVIth International Congress of Roman Frontier Studies, Rolduc 1995 (Oxford 1997), p. 603-608

M. Zahariade, D. Lichiardopol, Componenţa şi structura armatei romane nordul Munteniei, între anii 101-117 (The Composition and Structure of the Roman Army in Northern Wallachia in A. D. 101-117), in Dacia Augusti Provincia, p. 121-134 
Pl. I. 1. The world according to Agrippa (apud Mattern 1999, 50 fig. 4); 2. The map of Ptolemy (apud Zahariade 2009, 365 fig. 3 after Strang manuscript); 3. Tabula Peutingeriana (apud Talbert 2010)

Pl. II. 1. The representation of the lower course of the Danube on modern maps: 1. Petrus Kaerius - $1650 ; 2$. Giacomo Giovanni Rossi - 1684; 3. Jean Baptiste Nolin - 1716

OVIDIU TENTEA Muzeul Național de Istorie a României Secției de Arheologie Pre- şi Protoistorică, Clasică şi Medievală ovidiu.tentea@gmail.com 


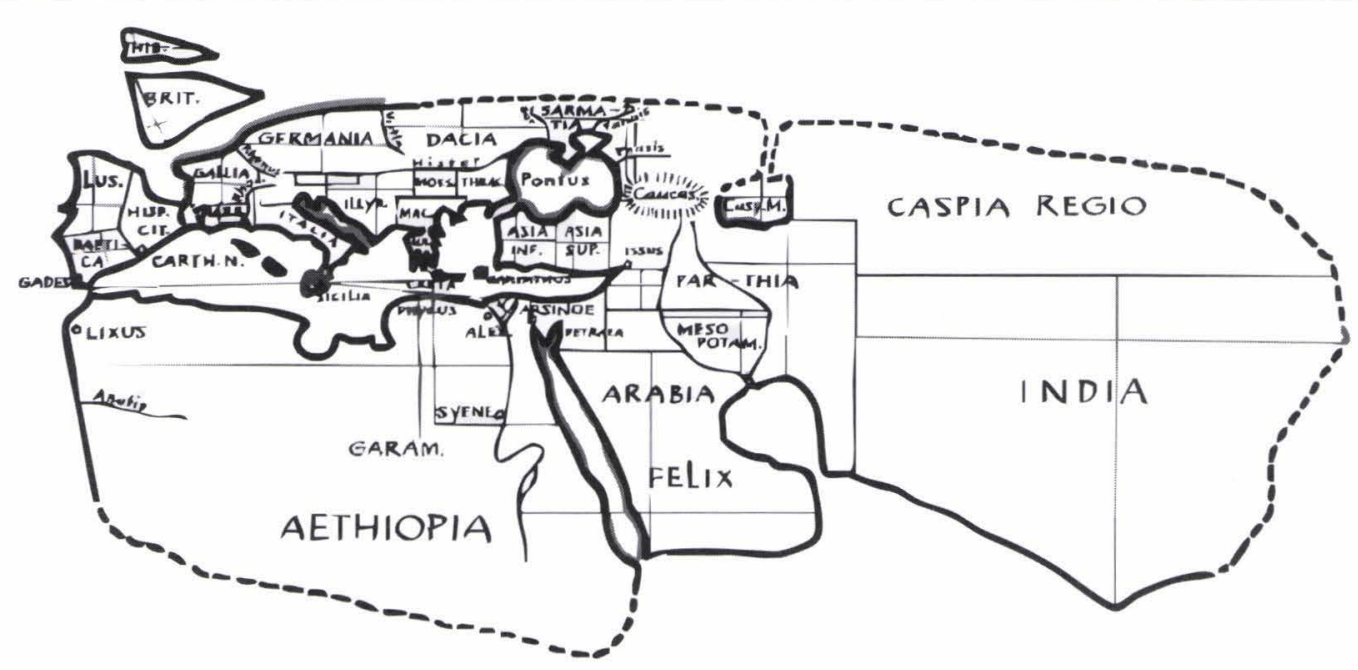

1.

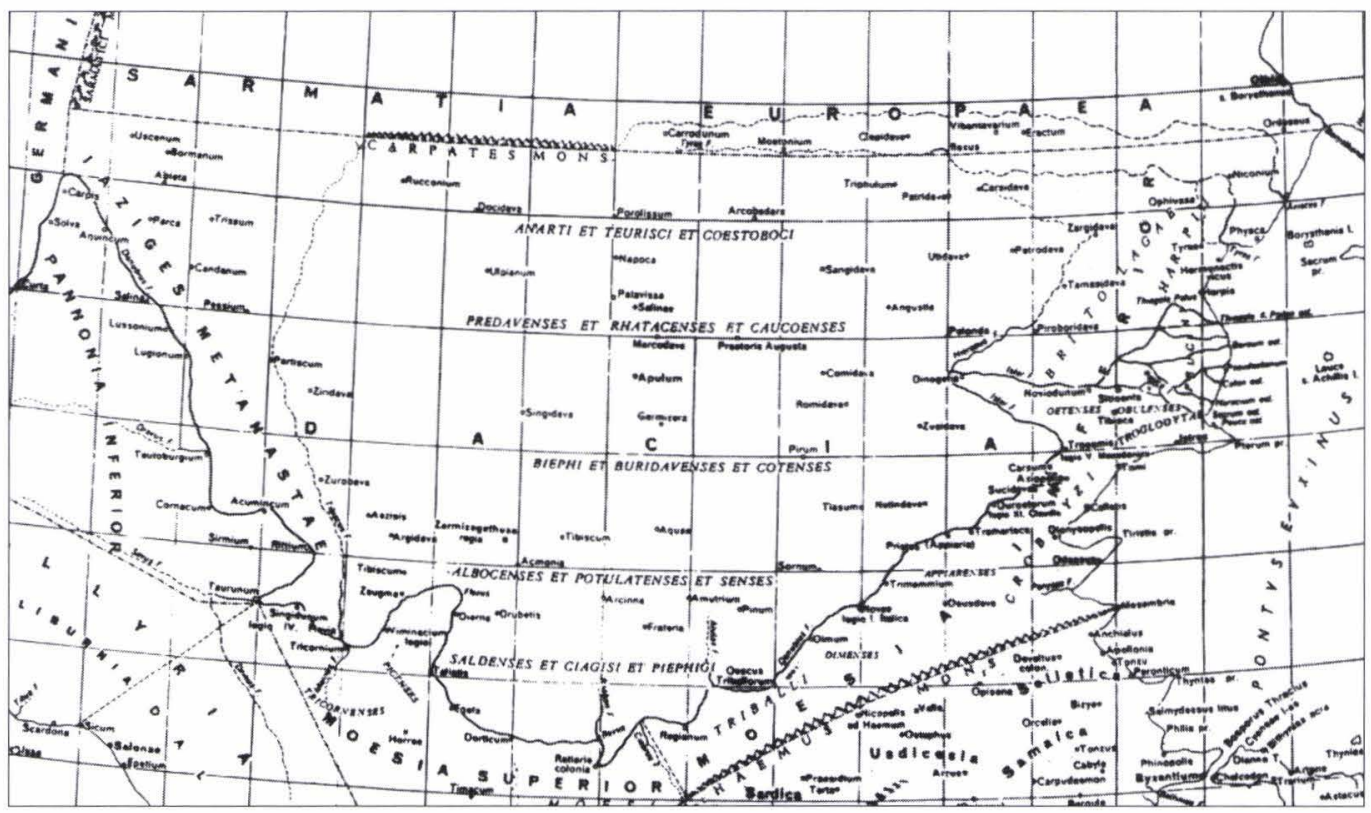

2.

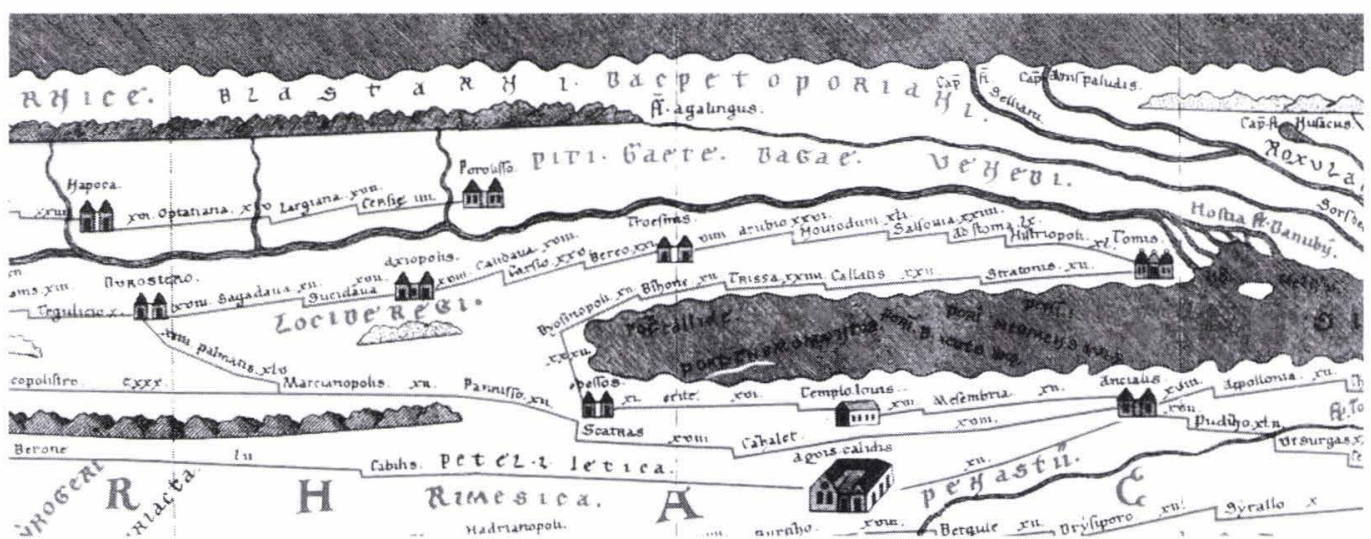

3.

1. Reprezentarea Lumii după Agrippa (apud Mattern 1999, 50, fig. 4); 2. Harta lui Ptolemeu (apud Strang mss.); 3. Tabula Peutingeriana (apud Talbert 2010) 


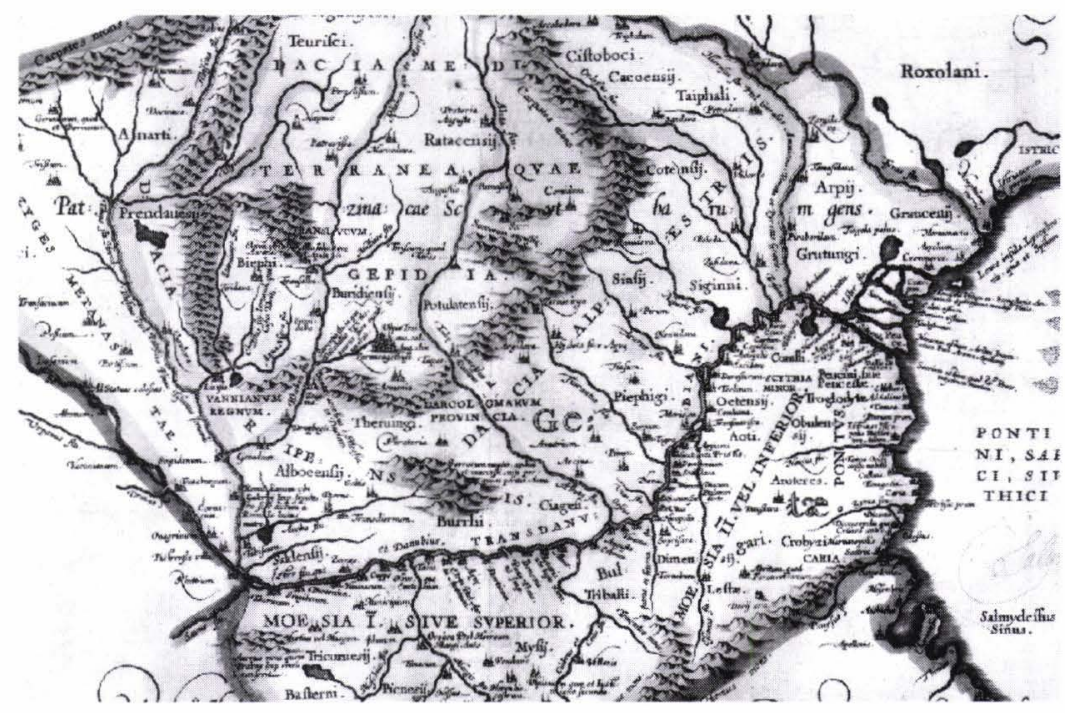

1.

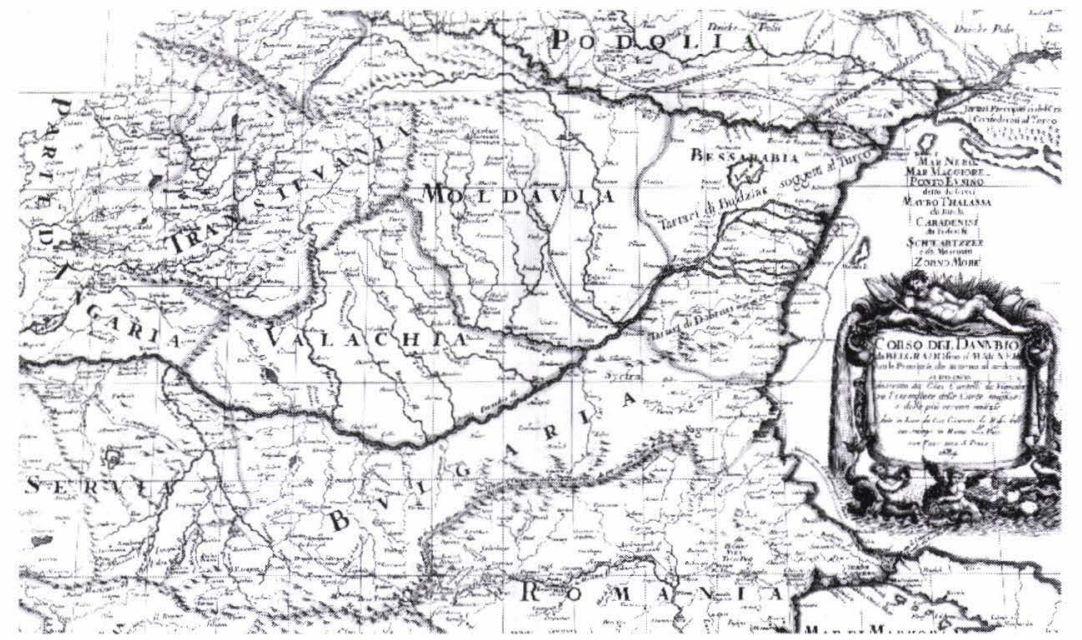

2.

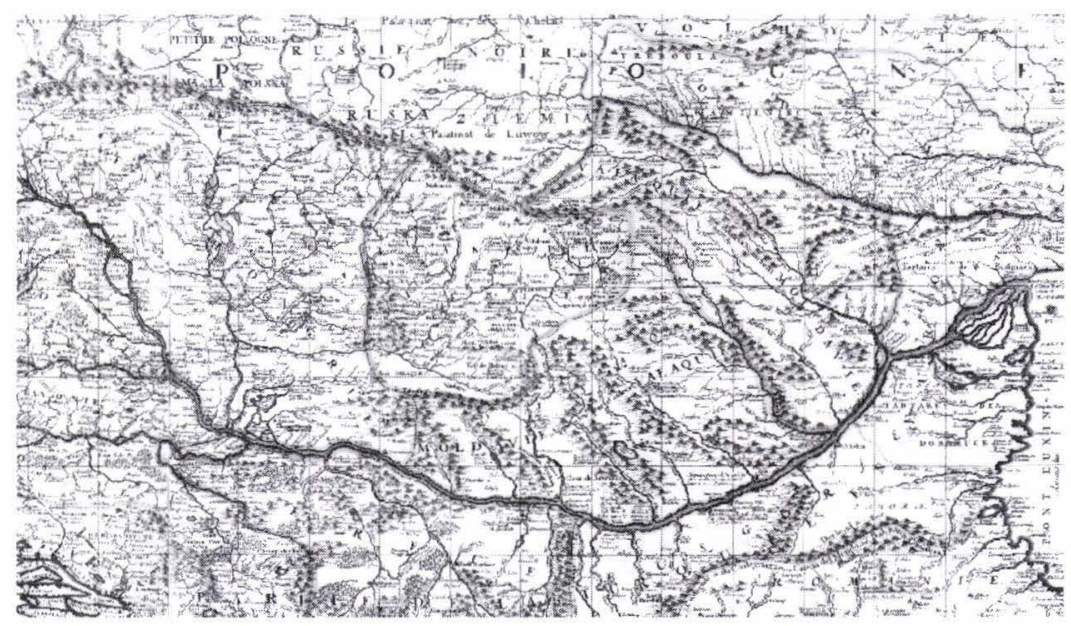

3.

Reprezentarea cursului inferior al Dunării în hărți moderne: 1. Petrus Kaerius - 1650; 2. Giacomo Giovanni Rossi - 1684; 3. Jean Baptiste Nolin - 1716 